\title{
Vera Höke Individualisation in conformity: Keshab Chandra Sen and canons of the self
}

The Brahmo Samaj, one of the earliest and most important Indian social and religious reform movements, shared with liberal Christian thinkers and like-minded philosophers a remarkable emphasis on the self. The 'Brahmo Self' was intellectually related to a complex tradition that was shaped by Puritan practices of scrupulous self-examination and faculty psychology, a philosophical paradigm concerned with the nature of man and the relationship between vices and virtues, faculties and will. Both traditions contained the notion of a self that could, and needed to, be balanced, checked, and thereby improved or developed. For the first twenty years after it was founded, the Brahmo Samaj presented itself as representing a particular strain of philosophy, namely the Advaita Vedanta. In this context, the relation between man and divine was a pivotal point of discussion. Moving back and forth between these discourses on the self, the emergent self-constructions reflected certain social constellations and problems within this religious community.

Keshab Chandra Sen (1838-1884), a leading figure of the prominent nineteenth century Bengali reform movement Brahmo Samaj (roughly translatable as Society of God) from the late 1850s until his early death in the 1880s, produced an enormous number of lectures and designed several religious rites that centred on the individual as the very basis for the realisation of religious knowledge. He tirelessly emphasised the necessity of a 'living religion', presupposing that 'God is not dead, and the channels of inspiration are not shut up' (Sen 1904/1879, 437). Aiming for God-realisation by turning 'inwards' (antare), his writings were no less characterised by the urge for religious and social reform, linked to discourses of the 'development' of the Indian people. Sharing the notions of many of his contemporaries, Indian intellectuals and Westerners alike, he cherished neither the religious traditions that dominated popular religious culture in Calcutta nor the Brahmanical 'high-culture', with its reliance on ritual accuracy, outward duties, and dietary confinements. While generally welcoming Western culture as superior to Indian culture in its contemporary condition, he believed that this superiority was confined to the present and did not extend into the future. He was convinced that providence held a special place for India and Indians in the history of mankind.

The Brahmos, as they came to call themselves from the 1840s onwards as part of their development of an identity that set them apart as a confined religious community (Hatcher 2001), belonged to a middle class that was tied particularly 
closely to the British colonisers. Many of the great Bengali families had laid their financial foundations in the eighteenth century by working for the British East India Company as translators (dubashees) or traders and moneylenders (banyans). In the early nineteenth century, members of the middle class were successful in building up trading companies and indigenous banking houses, and were able to establish themselves as jamidars, the (mainly absentee) landlords of rural Bengal. But their financial success did not last. Financial crises in the 1830s and 1840s undermined their wealth and almost all of them were pushed out of trade and banking. Their elite position thus became more precarious, with their sources of income narrowing to what could be earned serving the British administration in the then capital of the British Empire in India. This class of people, now more dependent on a thorough education than ever, had long since turned education into one of the fundamental characteristics of their identity. They called themselves bhadralok, a term that literally reflected the English 'gentleman', and was understood to designate a 'civilised' or 'good mannered' person. According to their own perception, it was their education that distinguished them from the uneducated masses, the 'small people' (chottolok), on the one hand, and from old Indian aristocracy, on the other (Bhattacarya 2005; Sarkar 2011). Yatna, relentless efforts and industry, which had already played a major role in precolonial educational literature, remained one of the most important lessons to the educated youth of Calcutta. Yatna came with a promise: children that were lazy and disregarded their parents would have a dark future life, whereas those that applied yatna to their behavior in regards to education would be able to achieve anything they aimed for (Hatcher 1996). This attitude was not confined to their own class; it was applied especially to the lower classes, in a manner that carried strong paternalistic overtones (Bhattacarya 2005). This middle-class, which encompassed individuals of differing social status, thus valued education highly as a means to uplift the individual from a state of ignorance and end the deplorable state of the Indian people, as well as, often, its only source of employment and income. It was within this general framework that the encounter with Western, as well as Indian, traditions and philosophies took place.

In an earlier article on individualisation in the Brahmo Samaj (Höke 2015), I concentrated upon the particular way in which notions of Avatarism, the theory of 'Great Men' as developed by Thomas Carlyle and Ralph Waldo Emerson, and the Gaudiya Vaishnava practice of raganuga bhakti sadhana' were fused into a set of unique practices, called sadhu samagama, or 'Pilgrimages to the Saints'. I attempted to observe closely how Indian, European, and American traditions were linked within a religious framework that was generally informed by and open to both streams of thought. Its leading principle, 'intuition', allowed free borrowing from anything cherished in religious traditions. My discussion there 
was based on the premise that linguistics, in conjunction with social processes of translation, played a central role and the argument I develop in the present chapter progresses along a similar line.

Although the discursive construction of the self by no means exhausts the processes of what we call 'individualisation', it was an important part of the way these processes were reflected and consciously set into motion in late eighteenth and nineteenth century Europe, America, and India. In this paper, I will concentrate on two decisive elements in the construction of the self in the writings of Keshab Chandra Sen. First, I will show that his expectation that one observe, critically examine, and develop the self, often has to be framed within the context of the faculty psychology of Scottish Common Sense Philosophy and overlapping with practices of self-examination that had a long history in Protestant piety. Second, I will discuss his treatment of the self, which emerges from his reflection on the discourses of Indian Vedantic traditions. Keshab's notion of the self falls somewhere between a position that identifies the atman (the individual self) with the brahman, and a position that involves the passionate veneration of a personal Godhead as cultivated in bhakti-traditions, which latter presupposes a relation and therefore a discrimination between the worshipper and the worshipped. These elements, self-examination and self-cultivation on the one hand, and the relationship between the divine and the self on the other, were pivotal features of the notion of the self in Brahmo discourse. Whereas practices of self-examination and self-cultivation were, as we will see, part of a framework that was more globally acknowledged and that could be put into use for different ends, the wide-ranging and open discussion of the relationship between man and the divine contained elements that were for several reasons confined to India. There was not only a long and encompassing tradition of discussing these matters, which had to be addressed by the Brahmos as a part of the traditions they had grown up with, but also a certain reluctance on the part of Christians to question the personality of the godhead to the extent that was possible in India. ${ }^{1}$

A related element, concerning the exaltation of the individual self as the decisive authority in religious matters, is much too encompassing to be dealt with here. It should be sufficient to note that no religious knowledge that depends on outside authority, whether ascribed to persons or to books, could ever supplement the immediate, direct encounter with the divine for most of the authors discussed here. However, the cultivation of the self as part of, and yet as something above,

1 Among the New England intellectuals, it was Ralph Waldo Emerson who, at least partly inspired by his readings of Indian philosophy, went furthest in his idea of an impersonal godhead. In doing so, he provoked a huge wave of protest that encompassed even the most liberal Christian thinkers, expressing and emphasising the absolute need for a personal god. Grodzins 2002, 115-27. 
society and in a dual relationship with the divine was not only a prerequisite for immediate knowledge of the divine but also the way to gain such knowledge, as it led to encounters with the divine. Self-reliance was a term that was prevalent beyond the circles of New England's intellectuals; it also informed many of the practices of the Brahmo Samaj, especially in the New Dispensation Church. ${ }^{2}$

Regarding processes of individualisation, this analysis also emphasises that even though religious actors may insist on the necessity of religious immediacy and individuality, they never do so in a vacuum. On the contrary, they rely on canons of knowledge, only some of which were handed down to them in the form of written texts. Others were transmitted orally or as religious practices, with which the historical actors engaged, were inspired by, and sometimes refuted. This article does not aim to analyse processes of 'individualisation' in the Brahmo Samaj generally, but rather seeks to show how discussions of the 'self' relied on different canons of knowledge, some of which were shaped by Christian approaches, others by Hindu discourses.

\section{The self as subject of examination and improvement}

That the English term 'self' was a word prominently used in Keshab's English publications is undoubtedly linked to the importance attached to the term in the English and Northern American traditions he interacted with. Protestant traditions in England, and even more so in America, had a long history of concentrating on the self as a subject of reform. Americans had, from the late seventeenth century and through the entire nineteenth century, been speaking freely about 'the importance of constructing the self properly' (Howe 1997, 3). The time between the American Revolution and the Civil War has been singled out as a period during which discussions of selfhood and identity exploded and brought about shifts in language. Whereas some terms, such as 'self-government', 'self-culture', and 'self-reliance' emerged for the first time, older terms, such as 'self-denial' and 'self-improvement' became vested with new meanings (Masur 1991, 191). David

2 The New Dispensation Church (nava vidhan) emerged as the result of several schisms in the Brahmo Samaj. The 'Brahmo Samaj of India' (Bharatbarshiya Brahmo Samaj), founded in 1866 as a distinct branch of the movement and headed by Keshab Chandra Sen, further split up in 1878, after a time of severe criticism of Keshab, and the manner in which he developed his thought and style of leadership. Two years later, early in 1880, Keshab applied the name 'New Dispensation' to his own movement, and declared it to be a further step in the course of religious progress. 
Howe, in his monograph on Making the American Self, regards the conscious performance of acts of self-construction specifically as the exercise of a practice, albeit one that was mainly achieved verbally (Howe 1997, 4). The 'self-made men', as heroic ideal of the nineteenth century, was by no means confined to successful entrepreneurs. Rather, suggests Howe, the self-made man was,

one who had attained eminence by his own efforts in any walk of his life, not necessarily in business, and not just in monetary terms. The process of becoming self-made was understood as the development of human potential broadly conceived. Finally, what distinguished the self-made man was that his identity was a voluntarily chosen, conscious construction, not something that had to be achieved by an individual in isolation.

(Howe 1997, 136)

One element that contributed to the discourse of the self in England and America was the 'polite culture', inherited from Scottish enlightenment. Linked to the goal of a free society, the 'essence of polite culture was the balanced cultivation of the self [...]. The cultivated gentleman or lady, the responsible citizen, the objective observer of society: this was the ideal self' (Howe 1997, 55). 'Balance of character' was the highest aim in the cultivation of the self, embedded in the paradigm of 'faculty psychology', likewise inherited from Common Sense philosophy. 'The psychology of the age', writes Howe,

taught that human nature could be analyzed in terms of certain components, such as the "understanding" (powers of awareness, including both sensation and reflection) and the "will" (powers of action or motivation). Among the powers of will could be distinguished a variety of human motives, typically arranged in a hierarchically defined sequence of "faculties". The moral and rational powers (because they partook of the divine nature) had precedence over emotional and instinctive impulses (animal powers). Last of all came the mechanical reflexes (vegetative powers), over which there was no conscious control. Those powers that were under some degree of conscious control could be cultivated or restrained by the exercise of will.

(Howe 1997, 5f.)

Exercising control over the faculties and strengthening the moral and rational powers was of utmost importance, as the higher faculties in the sequence of rightful precedence were considered to be much weaker than the animal powers. Conscience was not only supreme but also the weakest of motives. Within this framework, self-interest was not necessarily repudiated. Instead, self-interest could also be considered a rational faculty, as long as it was kept in its place, guided by prudence, in the sense of self-preservation, and balanced with conscience, the moral sense (Howe 1997, 12f.).

This whole strain of thought developed within the framework of Christian thinking and values. First, Scottish Common Sense was related to reformatory aims within the Church of Scotland (Howe 1997, 50-2). In America, where the paradigm 
was widespread and dominated the political discourse, it not only became part of the thought of liberal Christian groups but was also taken over by Evangelicals. The act of critically observing the self, and developing and improving it accordingly, was often as much a question of having the freedom to do $\mathrm{so}^{3}$ as it was a moral obligation. As a practice that relied on observing the individual, the individual bore a great deal of personal responsibility. The individualism it brought forth did not stand in polar opposition to a strong sense of community. Projects of self-discipline could, rather, to cite Howe, 'be undertaken collectively as well as individually' (Howe 1997, 5).

The habit of keeping self-observational pocketbooks or diaries, a practice particularly cultivated by the Puritans in England and New England, overlapped with faculty psychology and was probably no less influential in shaping the notion of the self as an object of scrupulous examination. In Puritan theology, self-examination was closely linked to predestination. By self-examination, 'each person ought to seek to discern the twin signs of election in his or her life: the inward testimony of the Spirit and the outward evidence of sanctification'. ${ }^{4}$ Only by questioning their heart and by questioning their life could Puritans know whether or not they belonged to the elected few who were saved by God. But diaries were not only used to reflect on and investigate one's own self. These writings, when shared, could serve as spiritual stimuli with an effect similar to that of listening to sermons or regular readings of biblical texts (Bremer 1995, 21). Self-examination also became a crucial part of the wider genre of conversion narratives that gained importance in the Christian 'Awakenings' of the eighteenth and nineteenth century in America and England. Apart from Puritan and NonConformists sources, this mainly Evangelical genre also relied on the practices of self-examination of German Pietists, such as Philipp Jacob Spener (1635-1705) and August Herrmann Francke (1663-1727). Although the Pietism movement was slightly earlier than that of the Awakenings taking place on the British Isles and in northern America, both phenomena were closely interrelated (Welch 1972, 15).

Although the Unitarians and Transcendentalists did not generally cultivate the practices of writing conversion narratives or of keeping self-observational diaries, the latter practice was not entirely unknown. ${ }^{5}$ However, focusing on

3 The freedom of developing oneself was not naturally a given for people of lower status, women or black people in the late eighteenth and early nineteenth century.

4 The link between self-examination and predestination was already established by William Perkins (1558-1602) in the sixteenth century. Hindmarsh 2005, 36.

5 Caroline Healey Dall, for instance, first started to write her diary under the influence of this impulse. Dall was part of the inner circle of the transcendentalists and was married to the Unitarian missionary Charles Dall, who spent the best part of his life as a missionary in India and became the only Christian ever to be initiated into the Brahmo Samaj. See Drees 2005. 
the self still became a decisive part of their teachings and writings. The region in which these movements mainly developed - Boston, New England - was a stronghold of Puritanism in the late eighteenth and early nineteenth century. This widespread notion of a self that needed to be questioned and examined critically but that could also be developed and improved found a prominent place in the discourses of liberal Christians, being informed by Puritan practices as well as the paradigm of faculty psychology. The Unitarian Monitor, a fortnightly publication of American Unitarians, cites a book by William Sullivan intended for schools:

A self examiner may be supposed to ask himself such questions as these: Have I duly con-
sidered my bodily frame, and its wonderful constitution, and uses; - have I endeavoured
to preserve it in a fit condition to render to myself, to my connexions, to society, and to
its Creator, the duties for which he ordained, and gave it; [...] what account have I to give,
of the week that is gone; have I learned any thing; am I wiser or better, or more worthy of
my own respect, and that of others, then I was on the last sabbath; have I let the hours
run by unmarked, by any useful act of mine; [...] have I done to others, as I would that
they should do to me; have I escaped vain and criminal anger; have I said of any one,
unlawfully, that which I should not dare to say to him; have I been gentle, charitable,
civil, cheerful, kind hearted; have I rendered that which is due; have I made promises,
which I cannot perform, or any which I should not make; whom have I offended; [...] if
my peace of mind is disturbed, if a blush tinges my cheek, if a sigh burst from my heart,
if a tear dims my vision; must this have come over me, or could I have prevented it; [...].

(Sullivan, cited after Unitarian Monitor 1831, 102)

This quote contains several hints towards the ideals involved in the cultivation of the self, such as the instrumental use of the body to fulfill one's duties towards oneself, one's kin, society, and God, or the absolute control over, or even subdual of, any kind of emotion. However, what I want to draw attention to here are the practices of formulating concrete questions that lead to a scrupulous investigation of one's everyday behavior and of rendering an account of the past week, which seems to imply a regular execution of this practice.

William Elleray Channing's (1780-1842) lectures and writings may serve as another example here. In an introductory remark to a public lecture series held in 1838, published in 1839 as an essay entitled 'self-culture', Channing defines the venture of cultivating the self as 'the care which every man owes to himself, to the unfolding and perfecting of his nature'. 'Self-culture', he emphasises, 'is something possible. It is not a dream' (Channing 1839, 9). Self-searching, 'the faculty of turning the mind unto itself; of recalling its past, and watching its present operations', is only a preliminary step towards the power of forming the self by seeing 'in ourselves germs and promises of a growth to which no bounds can be set, to dart beyond what we have actually gained to the idea of Perfection as the end of our being' (Channing 1839, 10). Distinguishing several dimensions 
of self-culture, ${ }^{6}$ Channing places it in the context of the relation of the individual to society and the world, on the one hand, and the relationship with God, on the other, the two being intimately connected (Channing 1839, 13-5). Focussing on the social dimension of self-culture, Channing singles out aspects of the self that 'must be discharged' and repressed (Channing 1839, 12f.). He shows a more sceptical approach to self-interest than the Scottish Enlightenment philosophers mentioned above, although their approach to the issue was popular among Americans in general. Thomas Carlyle (1795-1881), the great Scottish philosopher and essayist, went even further in calling for the 'Annihilation of the self', so that 'Life, properly speaking, can be said to begin' (Carlyle 1838, 192-7). The emphasis on selfishness and self-seeking as parts of human selves that are to be overcome sometimes leads to the apparent ambivalence of a discourse centring on the self that seeks to annihilate itself.

\section{The self as atman?}

The notion of atman in Indian philosophy and religion, usually translated as 'self' in English writings, has been the subject of much discussion for hundreds of years. While atman is already mentioned in a more limited sense in the earlier genre of the Brahmanas, the concept of atman is first developed within the Upanishadic tradition, ca. 700-200 BCE (Malinar 2009, 45-9). Here it is an immortal part of the human being that is already liberated and only dwells inside the body to leave it after death, either to be re-embodied or to be released and never to appear again. Later schools of Vedanta (literally: the end of the Vedas) dissented greatly, particularly on the question of the relations between the divine, the material world, and the individual 'self'.

On a spectrum between dvaitic (dualistic) and advaitic (non-dualistic, sometimes termed 'monistic') positions, two interpretative poles were available. At the dvaitic end of the spectrum is the idea that there is a personal God from whom human atman will remain a separate entity altogether. At the other end, the extreme advaitic position, all differentiation is just mistaken perception that is to be eliminated by knowledge (jnana) and the realisation that the atman is nothing apart from the tranquil, transcendental consciousness (brahman). This debate encompassed many different positions articulating complex models of the relationship between the divine, man, and the material world. I will confine myself here to those of particular importance in the Bengali context: the already mentioned position of Advaita

6 The moral, religious, intellectual, social, and practical dimensions. See Channing 1839, 15-21. 
Vedanta, most popularly formulated by Shankara in the 8th/9th century CE, and that of Acintya Bhedabheda (roughly translatable as 'inconceivable non-difference in difference'), as it was developed by Jiva Gosvami, a 16th century follower of the great Bengali (that is: Gaudiya) bhakti saint Caitanya (see Gupta 2007). Shankara's position of Advaita left a lasting impression on succesive generations of those who discussed Vedanta philosophy, and although there are some interesting twists and turns in the relationship between the Gaudiya Vaishnavas and Advaita schools, ${ }^{7}$ the former came to regard the latter as their 'archrivals' (Holdrege 2015, 40). But these claims of absolute opposition between Gaudiya Vaishnavas and Advaitins should perhaps not be taken too seriously. Although the Advaitins served as the rhetorical 'Other' for Gaudiya Vaishnavas, there are mediating figures, such as Sridhara Svami (14th century), who was acknowledged as the greatest commentator on one of the most important texts of the Gaudiya Vaishnava tradition, the Bhagavata Purana, despite being a samnyasin (renouncer) of a Shankarite order (Gupta 2007, 40).

For Advaitins, brahman, the absolute Being, without form and characteristics, is the highest principle. Personal forms of the Divine are but inferior approaches to brahman, useful only for those who are incapable of approaching the formless. In contrast to this, the Acintya Bhedabheda has it that Krishna, in the form of the cowherd (gopala) in the heavenly realm of Vraj, is the true form or nature (svayamrupa) of the divine, and its only independent, complete form. By developing what Barbara Holdrege calls an 'encompassing hierarchical taxonomy', the great Vaishnava theologian Jiva Gosvami subsumes all other forms of the divine, including brahman, as subordinate, dependent aspects of Krishna (Holdrege 2015, 50f.). The way of the Advaitins is not, then, declared to be completely wrong but, rather, an incomplete and partial truth.

The approach to dealing with earlier, rival traditions is similar in both cases: Advaitins as well as Gaudiyas posit hierarchical models of the divine which incorporate, domesticate, and subordinate, rather than succeed, the earlier traditions (Holdrege 2015, 44). Apart from differences regarding the true form of the divine, it is also the choice of different ways (path) and ultimate goals that distinguishes Advaitins from Gaudiyas: Shankarites single out knowledge (jnana) as the only means of understanding the true nature of the atman as undifferentiated from

7 Caitanya himself had taken a vow as a samnyasin (an Advaitin renouncer and wandering ascetic) early in his youth, although he was probably initiated into a form of Advaitin sect that was inflected by bhakti (see Holdrege 2015, 41). Furthermore, the name of one of his well-known followers was Advaita Acharya, literally the teacher of Advaita. This phenomenon was an issue discussed by his followers, who found an explanation that did away with any engagement with the tradition of Advaita by reading into it an expression of the non-difference (advaita) between Advaita Acharya and Caitanya. See Manring 2005, 36 and 57. 
brahman. This insight alone can free the jiva, the individual being, from the cycle of rebirths (samsara) and lead to salvation (moksha), the final absorption into brahman. To achieve this end, it is necessary to lead the life of a renouncer (samnyasin) (Bartley 2011). Gaudiyas single out bhakti, a term of manifold meanings that primarily denotes utter love (prema) and longing (viraha) in Bengal, as the appropriate means for approaching the divine. They do not aim for moksha but for a direct, loving relationship with Krishna. The relation of the divine to the atman, as well as the relation of the divine to the material world, is that of an inconceivable non-difference in difference (acintya bhedabheda), insofar as, in the end, all that exists is an emanation of one kind or another from Krishna. However, as the immutable and unchangeable Supreme Being, Krishna Gopala is neither touched nor affected by the processes of change to which humans and the material world are subjected. The material world is brought forth by the unconscious yet unavoidable activity of Krishna's powers, the shaktis. In contrast to Advaitins, who hold that the material world is a distracting illusion (maya), for Gaudiyas the world must be real, as it is an emanation from Krishna (Santideva 2000, 215-56). While some Vaishnavas, especially in rural Bengal, also led a life of renunciation, the mainstream practice is that of a grihastha form of participation, that of a householder who does not neglect his social duties but remains part of his family and extended kinship group. Another term that also needs to be considered here is ahamkara (the sense of I-ness), which brings forth the notion of the 'I'. Within Advaita, this 'I' (aham) is not related to the atman itself but is, rather, part of the extended self; it 'designates the individuated self represented in [...] jiva-consciousness' (Ram-Prasad 2013, 226-9). Given the complexities of the notion of atman, it seems that we lose something both on the side of atman as well as that of the term self when we translate the one into the other.

\section{The self in Brahmo discourse}

Advaita Vedanta and faculty psychology seem to be key issues for understanding the conception of the self within the Brahmo Samaj. Despite his emphasis on the universal elements of religion when writing and acting on the international stage, the founding figure of the Samaj, Rammohan Roy, had introduced the Advaita Vedanta into the movement right from the beginning in the late $1820 \mathrm{~s} .{ }^{8}$ He was

8 See Killingley 1993. Rammohan dealt likewise with Muslim, Hindu, and Christian sources, and expressed his religious worldview from within these traditions. It is not easy to see precisely how these are related to each other in his work, as he himself does not link them explicitly. 
the first to translate at least a part of the Upanishadic writings into Bengali. Debendranath Tagore and the group of like-minded people around him, who began to renew the Samaj in 1842, initially subscribed to Advaita philosophy as well. Brian Hatcher has translated and analysed an early publication of the Tattvabodhini Sabha, a society founded by Debendranath before joining the Brahma Samaj, many of whose members later turned towards the Samaj with their leader. The small tract, called Sabhyadiger Vaktrikta, was published in 1841. According to Hatcher, the contributions show what he calls a 'Bourgeois Vedanta', by which he means a version of the Vedanta that allows its authors to develop a different understanding and legitimation of their newly acquired social status. While they emphasise the immediate worship of the supreme self and rely on the Upanishads and other scriptural sources to authorise their arguments, they rarely refer to any of the subjects that are commonly associated with Advaita Vedanta. The 'metaphysics of atman and brahman; the relationship between ignorance (avidya) and illusion (maya); and the characteristics of an ultimate reality that is beyond name and form' (Hatcher 2008, 74) were of minor importance compared to the question of how to pursue a life in this world and the need for a balanced character. The first discourse, delivered by Shyamacharan Mukhopadhyaya, formulates this position clearly and gives an example of this strain of argument:

[...], when lust, anger, \&c. grow strong, careful effort to control the senses will be fruitless. If the senses are controlled but greed is not restrained, then no thief will be able to stop stealing. A person who fails to control his lust and anger will suffer all sorts of misfortunes. However, if he acts with all his senses properly regulated, he gains blessings in this life and the next. What's more, if it weren't for our senses, there would be no way to live our lives in this world. [...] the senses are at the very root of worldly life. To prevent the predominance of lust, anger, and the other vices, the countervailing virtues of shame, patience, \&c. were created. Therefore, respected members, dedicate your lives to the right cultivation of patience, sincerity, virtue, truth, \&c. and to the defeat of lust, anger, greed, delusion, pride, \&c.

(Hatcher 2008, 143)

Killingley discerns the three religious traditions with which Rammohan interacts as distinct modes in which he addressed different audiences. Muslim, Hindu, and Christian audiences were addressed separately by using the respective religious terminology and scriptural sources. Although he does not single out any of these traditions as more important for shaping his overall religious thought, Killingley emphasises that Rammohan presents himself solely as an exponent of Vedanta in his Bengali writings (see also Killingley 1982). Bruce C. Robertson regards Rammohan as a representative of Advaita and regards his universal religious thought as being governed by this self-understanding. According to Robertson, the terminology Rammohan used in his English writings was misleading. It not only led to a mistaken view of his philosophy among Unitarians but also among successive generations of Brahmos (see Robertson 1995). 
The useful purpose of the senses and self-interest, when subdued to nobler motifs and countervailed by virtues in a balanced character, seems to echo some of the ideas formulated by faculty psychology. Although Hatcher does not, himself, use this term, he points out similarities with Scottish Enlightenment authors, such as Thomas Reid and Adam Ferguson. As the Scottish Enlightenment had become part of the curriculum of English-language schools, it seems very likely that the members of the Tattvabodhini Patrika were familiar with the key-writings (Hatcher 2007, 78). Rather than ascribing the similarities to the influence of these authors, Hatcher explains the attraction of these arguments by referring to the context of the successful bhadralok.

Whereas the conception of the divine as 'the Supreme Self, whose essential nature is consciousness' ${ }^{\text {9 }}$ remains rather closely related to classical formulations of Advaita Vedanta, the relation between self and God envisioned by Shankara later became a stumbling block for this philosophy in the Samaj. According to Debendranath Tagore's autobiography, the discovery of the metaphysics of atman and brahman was his pivotal reason for turning his back on Advaita Vedanta. He found it to be opposed to the relationship of man to god as that of a worshipper to the worshipped, which Debendranath declared to be the essence of Brahmoism. Even more so, the idea that worshipping the Supreme Being according to Vedanta would lead to liberation by annihilation of the individual consciousness (prithak samjnana) and absorption into that Supreme Being (nirbbanmukti) was to him a terrible sign of extinction. ${ }^{10}$ The duality of man and divine, incompatible with Advaita philosophy, was declared the basis of Brahmoism, despite its explicit insistence on the worship of an abstract, a-personal godhead. As a consequence, the Brahmo Samaj turned towards a more intuitive approach to the divine.

The scrupulous examination of the self, comparable to the practices of the Unitarians, became more important in the Samaj some twenty years later. If we are to follow Keshab's cousin and long-term companion Protap Chandra Majumdar, the practice of publically giving an account of one's own behaviour and misbehaviour and inviting others to comment on it critically, was already introduced in 1860, only three years after Keshab Sen had joined the Samaj. Describing the meetings of the Sangat Sabha, a small society within the Brahmo Samaj in which the participants were mainly the then young supporters of Keshab, he writes:

9 Discourse Five, written by Chandrasekar Deb. See Hatcher 2007, 150.

10 Tagore 2012, 80-4, see also the English translation: Tagore 1914, 160-5. 
They met frequently, and with fiery zeal for self-reformation, laid bare their whole hearts, freely and frankly discussed their own faults, courted mutual aid and criticism, and under Keshub's guidance made most genuine progress in spiritual and moral life.

(Mozoomdar 1887, 130)

Though Keshab increasingly turned towards Gaudiya Vaishnavism in his later years, practices of critical self-examination remained a part of his program. In the late 1870s, for example, the missionaries of the New Dispensation were expected to keep a spiritual diary. They were furthermore asked to write daily reports that had to be handed over to Keshab himself. ${ }^{11}$ Besides, self-investigating questions that bear a striking similarity to the catalogue reprinted in the Unitarian Monitor (cited above) were also to be found in the New Dispensation's journal:

Have you yet found out the work of your life, and discovered the means of carrying it out?
Have you found your place in the New Dispensation, the place every one is pleased to give
you with blessings and good wishes? What undoubted successes have you achieved in your
religious career? What passions have you completely conquered? How many souls have you
been the means of saving? What testimony can you give of having seen God, of having for-
given your enemy, of having abjured the love and care for worldly wealth, and turned your
home into a sanctuary? Do all those who know you best pass a favourable opinion of your
character?
(Sen 1916/1882, 121f.)

Furthermore, Keshab's strong predilection for the topic of sin (pap) likewise shows at least a partial relation to the need for scrupulous self-examination, and the promise that the self can be developed and improved. Original sin, he once remarked, was nothing but the liability of human beings to give in to carnal propensities (Sen 1904/1877, 368). The 'remedy' for this 'disease', i.e. the general liability to sin, was to be sought in the cultivation of the spiritual as well as the worldly life. He demanded that we "must so train and discipline ourselves, day after day, that we may rise above things of this world and enter into the spirit-world'. 12

11 Damen 1983, 170. Self-Examination as an important practice was by no means confined to Keshab alone. A number of lectures by the Brahmo Shivnath Shastri, who later became one of the leaders of a rival branch of the society, was collected and published in 1951 under the heading atma-pariksha ('Self-Examination'), a term that seems to be of relatively recent origin. The first of these lectures carries the title 'Self-Scrutiny - Through Other's Eyes and One's Own' in the English translation by Rajanti Kanta Das. Shastri, 1953.

12 Sen 1904/1877, 373. The term 'spirit world' introduced here hints at Keshab's idea of a separate realm that lies beyond 'worldliness', in which human beings were able to have immediate intercourse with 'Great Men' (sadhus). This scheme seems to be related to the ever-present heavenly realm of Vrindavan, accessible to the devotees by means of raganuga-bhakti sadhana. However, it is not possible to discuss this matter in detail here. For the Gaudiya Vaishnava notion of 
The concrete realisation of the discipline of the self is linked to a cultivation of the worldly life by means of 'ascetism' (vairagya) and spiritual life by means of 'practice' (sadhana). Vairagya was a widespread notion in the Indian traditions with which Keshab interacted. The term is mentioned in the Bhagavad Gita, one of most important sources of Krishna-bhakti (Bhagavad Gita 2.47-48, see Zaehner 1973, 51), and was also used by Shankara, the foremost thinker of Advaita Vedanta (Raveh 2012, 33f.). Whilst it is most commonly translated as detachment or non-attachment (Damen 1983, 158), Keshab chose to translate it as 'ascetism' in his English writings. To prevent misunderstandings, and probably to distinguish it from samnyasa, the ascetic ideal of the Advaitins, he eagerly distances himself from what he calls 'wrong ascetism'. The renunciation of the world, family, and children (i.e. taking samnyasa) he called the 'absurd and mean' aspects of ascetism, nothing but 'an error and a sin', and not more than 'pious selfishness' (Sen 1916/s.d.). The Brahmo Samaj always cultivated the form of grihastha-religion, that of householders remaining within the social structures of the family. Although Keshab in certain contexts advised some Brahmos to distance themselves much more strictly from family and friends than it appears here (Sen s.d./1876, 5f.), renouncing the world was in general not an alternative to being selfish, greedy, 'worldly'. There was no way of doing away with social duties and ties, even though they could turn out to hinder spiritual development. The emphasis on the need for 'the death of carnal nature' (Sen 1870/1868, 90) was not a merely theoretical issue but, rather, a practical one, although there is clearly a connection to the notion of examining and developing the self as advanced by the Unitarians, amongst others.

The community of close followers that Keshab had gathered around him was shaken time and again by problems and the misbehaviour of some of its members. He had placed on their shoulders the expectation of being a 'model brotherhood' that would serve as the germ of a social reformation, not only in India but for all mankind. However, the actual community fell short of the ideal (Damen 1983, 157-67). These conflicts can partly be traced back to financial shortfalls, suggesting that the emphasis on ascetism was also a way to turn a time of hardship into a virtue. After all, the need to set up strict rules 'for the subjugation of the carnal nature, for the regulation of worldly duties and desires', and to practice vairagya, 'which is only another name for simplicity and austere self-discipline', became

heavenly Vrindavan, see Haberman 1998; for the related set of practices called 'Pilgrimage to the Saints', see Höke 2015. 
more pressing in the face of what was perceived as 'the weakness and instability which have repeatedly characterised the lives of a great many Brahmos' ${ }^{13}$

While Keshab shared the prevailing estimation of conscience as the highest but weakest faculty, ${ }^{14}$ he shares Carlyle's call for a complete annihilation of the self, which he develops in much more detail. In this regard, it is Jesus Christ that sets the example to be followed. ${ }^{15}$ Turning towards the sayings of Jesus that 'I and my father are one' (John 10:30) and 'I am in my father and my father is in me' (John 14:11), he explains that Jesus was devoid of any 'individuality'.

These words clearly mean [...] nothing more than the highest self-denial. [...] Self must be extinguished and eradicated completely. Christ said so, and Christ did so. He destroyed self. And as self ebbed away, Heaven came pouring into the soul. For, as you all know, nature abhors a vacuum, and hence as soon as the soul is emptied of self [sic] Divinity fills the void. So was it with Christ.

(Sen 1883, 287f.)

A similarly radical stance is taken by Keshab in his writing on 'Objective and Subjective Yoga', a long article that explains his theory of Yoga to his American audience, first published in the New York Independent in 1883, shortly before his death. He explains that for 'Vedantic Yoga' (i.e. Yoga that looks for God in nature) 'material is the great obstruction', whereas in Keshab's own theory of 'Subjective Yoga' (i.e. introspective Yoga), the self is the problem that needs to be eradicated in order to achieve the union with the Divine:

This self-abnegation is not merely self-denial or asceticism in the ordinary sense of the term. It is not merely the renunciation of carnal pleasures and temporal enjoyments. It is not even the highest form of poverty. It is not mere sackcloth and ashes. It is something more. The sacrifice it enjoins is far more radical and deep. It is the sacrifice not of self-interest or selfishness or self-indulgence, but of self itself. The yogi hates self as an abomination and an evil in itself. [...] He will have no other salvation than the absorption of I, Mine and Me in the godhead.

(Sen 1883, 17f.)

It seems that he does not point to the dissolving of the atman in the brahman but, rather, to the sense of I-ness (ahamkara) and the 'I' (aham). That it would be misleading to translate the 'self itself' as atman in this context is shown by his introductory remarks on the meaning of Yoga:

13 S.a., 'Retrospect of the Year', Theistic Annual 1877, 2. While no author is given, this critical estimation was probably written by Pratap Chandra Majumdar, who edited the journal.

14 'Our conscience has the right to rule over us, but not the might'. See Sen, 1870/1868, 78.

15 On the peculiar practice of the Sadhu samagamas and their place between the Great MenTheory developed by Thomas Carlyle and Ralph Waldo Emerson and Gaudiya Vaishnava practices, see Höke 2015. On Keshab's overall conception of Christianity and the meaning of Jesus for religious history and practice, see Höke 2018. 
What does yoga literally mean? Union. [...] The created soul, in its worldly and sinful condition, lives separated and estranged from the Supreme Soul. A reconciliation is needed; nay, more than a reconciliation. A harmonious union is sought and realized. This union with Deity is the real secret of Hindu yoga. It is spiritual unification; it is a consciousness of two in one: duality in unity.

(Sen 1883, 1f.)

The unity thus remains a duality; the atman remains separate from the divine. The absorption of 'I, Mine and Me in the godhead' does not suspend the relationship of worshipper and the worshipped. It should be noted here that there is a movement between and on the edge of Western and Indian philosophical streams of thought. The balance of character as aimed for according to the widespread paradigm of faculty psychology is being connected to vairagya. In trying to make 'ascetism' a workable translation, it had to be distanced from samnyasa. The complete annihilation of the self as a preparatory step leading to the union with the divine is, for Sen, exemplified by no one else than Jesus Christ. This union, however, is one in which the duality of man and divine remains. Interweaving elements of the Indian and Western frames of reference, the usage of Western and Indian terminology to structure not only the religious argument but also actual practices in the community of Brahmos leads to a new understanding of both the Western and the Indian sources. Sadhana, religious practice as a 'method of realization' (Haberman 1988, 7), is another of those indigenous terms that are combined with Western ideas ${ }^{16}$ but that also leads far beyond the confines of the imagination of Western authors.

The necessity of developing a cultivated, well-mannered, self in society was the foundation upon which the shared intellectual discourses of the United Kingdom, North America, and India were based. In the nineteenth century, the notion of the 'self' was a key concept that was explicitly reflected upon and debated. The individual did not only bear a substantial amount of personal responsibility, interwoven with recurring elements of divine grace, but also had potentials that could and should be realised by self-cultivation. 'Self-interest' was deemed a necessary driving impulse, albeit only when tamed and subdued by the nobler faculties. In Calcutta, this strain of thought was integrated into a reading of Advaita Vedanta by members of the Tattvabodhini Sabha, many of whom would later become Brahmos. In the 1830s, when the Bengali bhadralok were still mostly successful entrepreneurs, this served to legitimise their new-found social status, as well as their entrepreneurial activities. In the 1870s, when the fate of many of those who

16 The Indian concept of sadhana was central for the practical side of religion within both the New Dispensation and the Brahmo Samaj of India from the 1870s onwards. Introducing sadhana as a novel feature in one of their newspapers, the Brahmos, tellingly, translated it as 'self-culture' in 1876. See Indian Mirror, Sunday Edition, 24.09.1876, 1. 
considered themselves as bhadralok had changed, with their lives becoming more precarious, self-interest was downgraded in the view of the Brahmo Samaj of India and the Church of the New Dispensation. Although the discourse remained centred on the self and the constant examination of one's own behaviour was conducted more scrupulously than ever, self-interest was something to be overcome and annihilated. While not allowing for a complete withdrawal from worldly duties, Keshab Chandra Sen cultivated an attitude of indifference towards worldly successes as well as disappointments. It was not coincidental that the emphasis on self-examination emerged at a time of trouble within his small community, it rather emerged as a solution to specific organisational problems and unrest. In contrast to how the self was discussed in the United Kingdom and America, in Calcutta these discussions became entangled with rival ideas, of being in or retreating from the world, that were peculiar to India. Practices of self-construction were related to Indian philosophical discourses; the discourse of the self thus became entangled with a more ontological perspective that focused on the relation between humans and the divine. The Brahmo Samaj shared an abstract, impersonal notion of the divine with Advaita Vedanta. Unlike the latter, however, the Brahmos considered the relationship between man and divine as that between worshipper and worshipped. This approach overlapped with the bhakti-attitude of the Gaudiya Vaishnavas, a tradition which gained importance in the 1870s and particularly in the area of spiritual self-cultivation. However, despite calling for an immediate encounter with the divine, this encounter was informed by different canons of tradition, on the edge of which the Brahmos developed their own ideas.

\section{References}

S.a. 'Retrospect of the Year', Theistic Annual 1877, 2.

Bartley, Christopher. 2011. 'Vedānta: Advaita Vedānta and the Schools of Vedānta'. In Brill's Encyclopedia of Hinduism 3. Society, religious specialists, religious traditions, philosophy, eds. Knut A. Jacobsen et al., Leiden: Brill. 719-35.

Bhattacharya, Tithi. 2005. The Sentinels of Culture. Class, Education, and the Colonial Intellectual in Bengal (1848-85). New Delhi: Oxford University Press.

Bremer, Francis J. 1995. The Puritan Experiment. New England Society from Bradford to Edwards. Hanover: University Press of New England.

Carlyle, Thomas. 1838. Sartor Resartus; The Life and Opinions of Herr Teufelsdröckh in Three Books. London: Saunders and Otley.

Channing, William E. 1839. Self-Culture. An Address introductory to the Franklin Lectures, delivered at Boston, September, 1838. Boston: James Munroe and Co.

Damen, Frans L. 1983. Crisis and Religious Renewal in the Brahmo Samaj (1860-1884). A Documentary Study of the Emergence of the 'New Dispensation' under Keshab Chandra Sen. New Delhi: Model Press. 
Drees, Helen R. 2005. Daughter of Boston. The Extraordinary Diary of a Nineteenth Century Woman: Caroline Healey Dall. Boston: Beacon Press.

Grodzins, Dean. 2002. American Heretic: Theodore Parker and Transcendentalism. Chapel Hill: University of North Carolina Press.

Gupta, Ravi M. 2007. The Chaitanya Vaishnava Vedanta of Jiva Gosvami. London: Routledge. Haberman, David L. 1988. Acting as a Way of Salvation. A Study of Raganuga Bhakti Sadhana. New York: Oxford University Press.

Hatcher, Brian A. 2001. 'Great Men Waking: Paradigms in the Historiography of the Bengal Renaissance'. In Bengal: Rethinking History. Essays in Historiography. ed. Sekhar Bandyopadhyay. New Delhi: Manohar. 135-63.

Hatcher, Brian. 1996. Idioms of Improvement. Vidyāsāgar and Cultural Encounter in Bengal. Calcutta: Oxford University Press.

Hatcher, Brian. 2007. Bourgeois Hinduism, or Faith of the Modern Vedantists. Rare Discourses from Early Colonial Bengal. New York: Oxford University Press.

Hindmarsh, D. Bruce. 2005. The Evangelical Conversion Narrative: Spiritual Autobiography in Early Modern England. Oxford: Oxford University Press.

Höke, Vera. 2015. "Approaching the rasa-lila of "great men": interlinking Western "intuitive" theologies with traditions of Bengal in the Brahmo Samaj', Religion 45.3. 451-76.

Höke, Vera. 2018. “'Other Sheep I Have”. Keshab Chandra Sen und der "asiatische” Jesus'. In Issues of Interpretation: texts, images, rites. eds. Carlo Altini, Philippe Hoffmann and Jörg Rüpke, Stuttgart: Steiner, 179-96.

Holdrege, Barbara A. 2015. Bhakti and Embodiment. Fashioning Divine Bodies and Devotional Bodies in Krishna bhakti. London: Routledge.

Killingley, Dermot H. 1981. 'Rammohan Roy on the Vedānta Sūtras', Religion 11. 151-69.

Killingley, Dermot H. 1993. Rammohan Roy in Hindu and Christian Tradition: The Teape Lectures 1990. Newcastle upon Tyne: Grevatt and Grevatt.

Malinar, Angelika. 2009. Hinduismus. Göttingen: Vandenhoeck and Ruprecht.

Manring, Rebecca. 2005. Reconstructing Tradition. Advaita Acharya and Gaudiya Vaishnavism at the Cusp of the Twentieth Century. New York: Columbia University Press.

Masur, Louis P. 1991. "'Age of the First Person Singular": the Vocabulary of the Self in New England, 1780-1850". In Journal of American Studies 25.2.189-211.

Mozoomdar, Pratap Chandra. 1887. The Life and Teachings of Keshub Chunder Sen. Calcutta: Baptist Mission Press.

Ram-Prasad, Chakravarti. 2013. Divine Self, Human Self. The Philosophy of Being in Two Gïtā Commentaries. London: Bloomsbury.

Raveh, Daniel. 2012. Exploring the Yogasutra. Philosophy and Translation. London: Continuum.

Robertson, Bruce C. 1995. Raja Rammohan Ray: The Father of Modern India. Delhi: Oxford University Press.

Santideva, Sadhu. 2000. Traditions of Mysticism in Bengal. New Delhi: Cosmo Publications.

Sarkar, Sumit. 2011 ${ }^{4}$. 'Kaliyuga, Chakri and Bhakti: Ramakrishna and His Times'. In Writing Social History, idem. New Delhi: Oxford University Press. 282-357.

Sen, Keshab Chandra. 1870/1868. 'Regenerating Faith'. In The Brahmo Samaj. Four Lectures by Keshub Chunder Sen, London: W. H. Allen. 75-94.

Sen, Keshab Chandra. 1904/1877. 'The Disease and the Remedy'. In The Brahmo Somaj. Keshub Chunder Sen's Lectures in India, London: Cassell and Company. 361-89.

Sen, Keshab Chandra. 1904/1879. 'India and India's Gods'. In The Brahmo Somaj. Keshub Chunder Sen's Lectures in India, London: Cassell and Company. 434-9. 
Sen, Keshab Chandra. 1916/ s.d. 'Ascetism'. In Essays, Theological and Ethical, Calcutta: Brahmo Tract Society. 198-200.

Sen, Keshab Chandra. 1916/1882. 'Paragraphs'. In New Dispensation, vol. 2, Calcutta: Brahmo Tract Society. $121 \mathrm{f}$.

Sen, Keshab Chandra. 1940 /1883. Yoga: Objective and Subjective. Yoga or Communion with God Reprinted from the New York 'Independent'. Calcutta: Nava Vidhan Publication Committee.

Sen, Keshab Chandra. s.d./1876. Brahmogitopanishat. Discourses on Yoga and Bhakti. Translated by J.K. Koar. Calcutta: Navavidhan Publication Committee.

Sullivan, William. 1831. The moral class book or, The law of morals, derived from the created universe, and from revealed religion: Intended for schools. Boston: Richardson, Lord and Holbrook. [cited after 'SELF-EXAMINATION', Unitarian Monitor. October 13, 1831. 102.]

Tagore, Debendranath. 1914. The Autobiography of Debendranath Tagore. Translated from the Original Bengali by Satyendranath Tagore and Indira Devi. London: Macmillan and Co.

Tagore, Debendranath. 2012/1898. Maharshi Debendranath Thakurer Atmajiboni. Calcutta: Alakananda Publishers.

Welch, Claude. 1972. Protestant Thought in the Nineteenth Century. Vol. I, 1799-1870. New Haven: Yale University Press.

Zaehner, Robert C. 1973. The Bhagavad-Gītā. London: Oxford University Press. 
